\title{
Origin of Life Prize
}

\author{
Alan W. Schwartz
}

Published online: 28 May 2011

(C) The Author(s) 2011. This article is published with open access at Springerlink.com

A retired west-coast (U.S.A.) business man has surprised the origin of life community by announcing a major prize for origin of life research. The $\$ 50,000$ award and up to $\$ 2,000,000$ in potential research funding are offered “...for the best original proposal pertaining to the study of the origin of life on Earth, including an outline of work to be performed..." The sponsor of the prize, Harry Lonsdale, will announce the competition at ORIGINS 2011 in Montpellier (http://www.origins2011.univ-montp2.fr/). While vaguely similar-sounding announcements have appeared before, this seems to be completely authentic and a panel of experts well-known to the community has been assembled to evaluate applications. Details can be found at: www.originlife.org.

Open Access This article is distributed under the terms of the Creative Commons Attribution Noncommercial License which permits any noncommercial use, distribution, and reproduction in any medium, provided the original author(s) and source are credited.

\footnotetext{
A. W. Schwartz ( $\square)$

Radboud University Nijmegen, Nijmegen, The Netherlands

e-mail: alan@sci.ru.nl
} 